\title{
Factors affecting the consumption of organic and functional foods in Brazil
}

\author{
Adalgisa Paula de Oliveira MARTINS ${ }^{1}$, Maria de Fátima BEZERRA ${ }^{1}$, Sérgio MARQUES JÚNIOR ${ }^{1}$, \\ André Fonseca de BRITO², Stela Antas URBANO ${ }^{1}$, Luís Henrique Fernandes BORBA ${ }^{1}$, Cláudia Souza MACÊDO ${ }^{1}$, \\ Juliana Paula Felipe de OLIVEIRA ${ }^{3 *}$ (D), Adriano Henrique do Nascimento RANGEL ${ }^{1}$
}

\begin{abstract}
The objective of this work was to investigate the factors which affect the consumption of organic foods enriched with functional properties. The study was developed by investigating the consumer profile of organic and functional foods by applying a questionnaire hosted on the Google Forms platform (docs.google.com/forms/). The obtained results show that individuals in the age group 31 to 40 years old and those 51 and older, widowed, divorced and inhabitants of the Midwest, Southeast and South regions consume organic food more often. The education level did not influence the willingness to pay more for the purchase of an organic food, the consumption frequency or the interest in consuming organic food with functional potential. The interviewee group had a monthly income of up to $\mathrm{R} \$ 4,686.00$ (In Reais - 5 minimum monthly salaries) and showed a consumption frequency between "almost never" and "sometimes", while those with an income higher than R $\$ 4,686.00$ presented between "sometimes" and "often". Residents of capital cities and from smaller cities showed similar behavior for all variables analyzed. We can conclude that the degree of confidence and the interest in consuming organic foods with functional potential were little influenced by socio-demographic differences.
\end{abstract}

Keywords: healthy foods; brazilian consumers; consumption frequency; quality of life.

Practical applications: Monitoring of the consumer profile directs the functional food production market. In addition, it is directly related to competitiveness, profitability, maintenance and market achievements.

\section{Introduction}

The organic food production system is highlighted by its concern for the environment, the welfare of farm animals, social justice and for supplying superior quality food without the presence of synthetic inputs such as fertilizers, pesticides, veterinary medicines, seeds and genetically modified breeds and preservatives (Food and agriculture Organization of the Unites Nation, 2016; IFOAM Organic International, 2016).

In this sense, the consumption of organic foods is driven by the desire for healthy, natural, sensory-pleasing foods (Chekima et al., 2017; Denver \& Christensen, 2015; Janssen, 2018) which are produced using methods that respect the environment and the animals (Gottschalk \& Leistner, 2013; Massey et al., 2018). In addition, the consumption of such foods can have positive emotional influences on the individual, leading them to perceive a greater degree of well-being and satisfaction with life (Apaolaza et al., 2018; Seconda et al., 2017).

When compared to conventional foods, organic foods tend to be considered better quality, healthier, tastier and more expensive (Bryła, 2016; Hwang, 2016). However, barriers such as high prices, insufficient knowledge on the part of the population, degree of confidence that the product purchased is in fact organic and low availability can make consumption difficult (Bozga, 2015; Buder et al., 2014; Yadav \& Pathak, 2016).
In turn, functional foods are able to favor prevention of various diseases and increase life expectancy (Annunziata \& Vecchio, 2016; Bezerra et al., 2014; Krauss et al., 2017), in addition to playing an important role in the sensory characteristics of food products in order to contribute to a better quality of life for consumers (Assmann et al., 2014; Mitsuoka, 2014).

Therefore, the objective of the present study was to investigate the factors which affect the consumption of organic foods enriched with functional properties through the relationship of socio-demographic characteristics (age, civil status, education level, income, region of Brazil and place of residence) with a willingness to pay more for organic food, the consumption frequency, degree of confidence and interest in consuming organic food with functional properties.

\section{Materials and methods}

\subsection{Sample typology}

The socio-demographic profile of the interviewees and the factors which affect the consumption of organic food in Brazil was assessed through investigation using a questionnaire hosted on a website, and structured with multiple-choice exploratory 
questions. A total of 1230 volunteers were interviewed, of which 385 were men (31.2\%) and 846 women $(68.8 \%)$. The responding public presented coverage in all age groups, civil status, education and monthly income, distributed across all regions of Brazil, both in the capital cities and in smaller cities in different states. All procedures were carried out with the authorization of Research Ethics Committee (CEP/UFRN), under license number (94022818.3.0000.5537).

\subsection{Data collection}

Data collection was performed using the snowball technique, which is applied in surveys conducted on social networks so that the first participants indicate new participants, who in turn indicate others and so on until reaching the proposed objective (Baldin \& Munhoz, 2011). Thus, an infinite population was considered due to the use of this technique given the non-possibility of determining a sample landmark, which generated a non-probabilistic sample.

The questionnaire was hosted on the Google Forms website, and transmitted via social networks (WhatsApp and Facebook") and e-mails from graduate students from several universities throughout Brazil. The data were collected during the months of February and March 2017. The questionnaire application used a branching logic resource provided by the referred website. This resource made it possible to direct the respondent according to their previous answer. Thus, individuals who never consumed organic food were directed to answer about which functional foods are most consumed.

\subsection{Structure of the research instrument}

The dimensions gender, age, civil status, education level, income, region of Brazil and location (capital city or smaller city) were evaluated according to the variables: PAGARM, FREQORG, CONFIAOR, and OFINTER. The results were collected based on the questions and answers described below:

A) Considering that organic foods come from a production system which respects ecosystems, people and animals in seeking the integrity of living beings and good quality of life for everyone involved, please answer the following questions:

PAGARM: There is a diversity of organic foods in Brazil, but in some cases they are sold at a higher price than conventional foods. How much more would you pay for organic cheese compared to conventional cheese? Responses issued by scale: 1 - would not pay anything more; 2 - would pay up to $10 \%$ more; 3 - would pay up to $20 \%$ more; 4 - would pay up to $30 \%$ more; 5 - would pay more than $40 \%$.

FREQORG: How often do you consume organic foods? Answers issued using a scale: 1 - never; 2 - almost never; 3 - sometimes; 4 - almost always; 5 - always.

CONFIAOR: Express how much do you trust that the food purchased is really organic. Responses issued by scale: 1 - I do not trust it; 2 - I trust it a little; 3 - Indifferent; 4 - I trust it; 5 - I trust it a lot.
B) Considering that functional foods promote significant health improvements when consumed regularly, minimizing the risk of various diseases such as diabetes mellitus, cancer and heart disease, answer:

OFINTER: How interested are you in consuming organic foods enriched with functional properties? Responses issued by scale: 1 - no interest; 2 - little interest; 3 - indifferent; 4 - interested; 5 - very interested.

\subsection{Statistical analysis}

The responses were collected directly on the website after the final questionnaire was completed, transferred to a Microsoft Excel ${ }^{\circ}$ spreadsheet, and the data were subsequently analyzed using the IBM SPSS Statistics version 22 statistical software program. The interviewee profiles were analyzed using descriptive statistical tools and the means were compared through the Tukey test to assess the variables of age, civil status, education level, income and Brazilian regions, as well as the Student's t-test for independent samples to assess the place of residence (capital city or smaller city). The means comparison tests were applied with a significance level of $5 \%$.

\section{Results and discussion}

\subsection{Interviewee profiles}

A total of 1230 volunteers of different age groups, civil status, education levels, income, from all Brazilian regions whether from capital cities or smaller cities of the states participated in this study. There was a greater participation of young people aged 21 to 30 years (47.8\%), followed by those between 31 to 40 years old (28.1\%) and adults aged 41 to 50 years old (10.5\%). Only $3.8 \%$ of young people up to 20 years old participated, and $9.8 \%$ of adults over 51 years old.

Most participants had completed postgraduate studies (49\%), 21\% said they had not completed their graduate studies, $12.4 \%$ had completed their undergraduate courses and $12.5 \%$ did not complete their undergraduate course. A small portion of the interviewees had only completed high school (3.9\%), did not complete high school ( $0.8 \%$ ), and only $0.2 \%$ of respondents had only completed their elementary school level. These results are attributed to the low representativeness $(3.8 \%)$ of the age group under 20 years old. With respect to income, $64.4 \%$ of the interviewees stated that they had a monthly income of up to 5 minimum monthly salaries ( $\mathrm{R} \$ 4,685.00), 22.8 \%$ had income between 5 and 9 minimum monthly salaries ( $R \$ 10,307.00)$, and only $12.8 \%$ above 9 minimum salaries.

The study counted on the participation of volunteers distributed in all regions of Brazil. The Midwest region had the highest percentage (32\%), followed by the Northeast (27.6\%), Southeast (21.4\%), South (11.3\%) and North (7.7\%). A little more than half live in the country's capital cities (53.3\%) and $46.7 \%$ in smaller cities of the states.

It is noteworthy that the survey represents only a section of the national population, as the Southeast region had the largest population (41.9\%) in 2015 according to data from 
the Brazilian Institute of Geography and Statistics (Instituto Brasileiro de Geografia e Estatística, 2016), while the Midwest region had the lowest number (7.6\%). Still according to Instituto Brasileiro de Geografia e Estatística (2016), more than half of the population aged 25 or over was concentrated in education levels up to complete elementary school or equivalent (52.0\%), 26.4\% had completed high school, and $13.5 \%$ had a college degree. With regard to income, $44.7 \%$ of Brazilian private households which declared to have some type of income had up to 1 minimum monthly salary per resident in the household, $32.5 \%$ were classified in the ranges of per capita household income from 1 to less than 2 minimum monthly salaries, and $19.9 \%$ reported per capita household income of 2 or more minimum monthly salaries (Instituto Brasileiro de Geografia e Estatística, 2016).

\subsection{Influence of age and civil status on the behavior of consumers of organic foods}

The results show that individuals aged 31 to 40 and 51 to 60 years are willing to pay more (PAGARM; $\mathrm{p}<0.05)$ when compared to other age groups. In addition, this group together with older adults (over 60 years) more often consume organic food (FREQORG), while young people under the age of 30 years tend to consume organic food less frequently (Table 1). Such findings corroborate the results published by Sinfh \& Verma (2017). The authors noted that Indian consumers aged 31 to 40 years purchased more organic foods.

The degree of confidence that the purchased food is in fact organic (CONFIAOR) was similar for all investigated age groups with averages between "indifferent" and "trust" (Table 1). Regarding the interest in consuming organic foods with functional potential (OFINTER), all presented averages corresponding to values between "indifferent" to "interested", and people over the age of 60 had a slightly lower average $(p<0.05)$. This small reduction in interest among older adults may be related to the higher price (Bryła, 2016; Bozga, 2015), even if they show availability to pay a little more or see them as tastier foods (Bryła, 2016).
Young adults, especially those with a higher level of education, consider the prices of organic food to be reasonable (Bozga, 2015), and they also show a higher degree of confidence (Bryła, 2016). Young people are more willing to seek healthy properties which contribute to improving their appearance (Kraus et al., 2017). Bryła (2016) states that the highest consumption frequency among young people is related to the quality of these foods and the concern with personal appearance and family health. Studies by Kraus et al. (2017) revealed that gender and age differentiate the motivations for consuming functional foods. For older women and men, safety, good health and a long life are the most important motivators for consuming these foods.

Regarding civil status (Table 1), it is clear that widowers are willing to pay up to $30 \%$ more for the purchase of organic food $(\mathrm{p}<0.05)$, while others would only pay between 10 and $20 \%$ more. Divorced, widowed and other types of union responded that they consume organic food (FREQORG) between "sometimes" and "almost always", while the frequency for single, married and stable unions is between "almost never" and "sometimes".

In FREQORG, widowers had similar averages to divorced and others, but different $(\mathrm{p}<0.05)$ from single, married and those in a stable relationship. Furthermore, the groups presented statistically similar averages to each other for the CONFIAOR and OFINTER variables. In CONFIAOR, the groups presented averages between "indifferent" and "trust". Divorcees slightly stood out for this variable because they presented a higher degree of confidence in relation to the others. For OFINTER, the groups presented averages between "indifferent" and "very interested", with emphasis on divorced people and other types of union which showed slightly higher interest in relation to the other civil status groups.

Widowers stood out in relation to other civil status groups because they showed a greater interest in paying a higher price for the purchase of organic food, in addition to having equal average consumption frequency together with divorced and other types of union, while single, married and stable unions

Table 1. Relationship between age and civil status with factors which affect the consumption of organic foods.

\begin{tabular}{|c|c|c|c|c|c|}
\hline & & PAGARM & FREQORG & CONFIAOR & OFINTER \\
\hline \multirow{4}{*}{ AGE } & $<20$ years & $2.49 \mathrm{~b}$ & $2.43 \mathrm{~d}$ & $3.15 \mathrm{a}$ & $3.87 \mathrm{a}$ \\
\hline & 21 to 30 years & $2.46 \mathrm{~b}$ & $2.68 \mathrm{~cd}$ & $3.16 \mathrm{a}$ & $3.97 \mathrm{a}$ \\
\hline & 41 to 50 years & $2.59 \mathrm{~b}$ & $2.95 b c$ & $3.10 \mathrm{a}$ & $3.88 \mathrm{a}$ \\
\hline & 51 to 60 years & $3.01 \mathrm{a}$ & $3.14 \mathrm{ab}$ & $3.53 \mathrm{a}$ & $3.93 \mathrm{a}$ \\
\hline \multirow{4}{*}{ CIVIL STATUS } & Single & $2.53 \mathrm{~b}$ & $2.71 \mathrm{~b}$ & $3.16 \mathrm{a}$ & $3.95 a$ \\
\hline & Married & $2.64 \mathrm{~b}$ & $2.99 \mathrm{~b}$ & $3.18 \mathrm{a}$ & $3.93 \mathrm{a}$ \\
\hline & Stable union & $2.44 \mathrm{~b}$ & $2.89 \mathrm{~b}$ & $3.13 \mathrm{a}$ & $3.72 \mathrm{a}$ \\
\hline & Divorced & $2.77 \mathrm{~b}$ & $3.11 \mathrm{ab}$ & $3.62 \mathrm{a}$ & $4.27 \mathrm{a}$ \\
\hline
\end{tabular}

a,b,c,d: averages in the same column with different letters show statistically significant differences by the Tukey test $(\mathrm{p}<0.05)$. 
showed a lower consumption frequency. These factors may be related to the awareness of these consumers about the benefits provided by this type of food to health, in addition to their concern with increasing longevity and environmental preservation (Lee \& Yun, 2015; Prakash et al., 2018).

\subsection{Influence of education level and income on the behavior of organic food consumers}

There was no statistical difference between the different education degrees for the PAGARM, FREQORG and OFINTER variables (Table 2). A significant difference for CONFIAOR $(p<0.05)$ was only observed between individuals who had up to the elementary level of education (they had averages between "I trust it" and "I trust it a lot") in relation to individuals with incomplete high school who had averages between "I trust it little" and "indifferent". The degree of confidence that the food purchased is in fact organic (CONFIAOR) was similar for individuals with completed high school, incomplete graduation, completed graduation, incomplete post-graduate and completed post-graduate degree.

All levels of education showed that they are willing to pay between $10 \%$ to $20 \%$ more for an organic cheese enriched with functional properties (PAGARM), except for individuals who have up to elementary level, who said they are willing to pay $20 \%$ to $30 \%$ more; even so, it maintained the statistical similarity. Respondents with up to the elementary level also stood out with a higher average for CONFIAOR ("I trust it" to "I trust it a lot") and OFINTER ["interested" to "very interested"]; however, this group only showed a difference for the CONFIAOR variable from the statistical point of view in relation to those with incomplete high school.

The results found in the present study are similar to the findings of Bryła (2016). The author noted that people from
Poland with a higher level of education reported that organic foods have a higher price and are healthier, while individuals with a lower level of education reported greater confidence and acceptance of the higher prices of these products, while health and the high quality of these foods are also important features to encourage consumption for both.

In the present study, we observed no difference in the behavior of respondents with different levels of education in relation to willingness to pay more for the purchase of organic food, consumption frequency and interest in purchasing organic food with functional properties. Such results contradict some other authors' findings, such as by Annunziata \& Vecchio (2016), Krauss et al. (2017) and Sinfh \& Verma (2017), who highlight that more educated people attach greater importance to functional components and prefer to buy organic foods.

Based on Table 2, it was found that income did not influence the degree of confidence or the interest in consuming organic foods with functional potential in the evaluated groups. The results for the PAGARM variable show that the interviewees, regardless of their monthly income, are willing to pay between $10 \%$ to $20 \%$ more to purchase organic food; however, there is a lower average for those who earn up to $\mathrm{R} \$ 937.00$ ( 1 minimum monthly salary; $\mathrm{p}<0.05)$ in relation to those who have a monthly income between $\mathrm{R} \$ 4,686.00$ to $\mathrm{R} \$ 6,559.00$ (5 to 7 minimum monthly salaries) and above $\mathrm{R} \$ 10,308.00$ (more than 11 minimum wages). It is worth noting that despite this willingness to pay more for organic food, Marian et al. (2014) states that high prices generate less repeat purchases.

The group of interviewees with a monthly income of up to $\mathrm{R} \$ 4,686.00$ (5 minimum monthly salaries) presented a consumption frequency (FREQORG) between "almost never" and "sometimes", whereas those with an income above R $\$ 4,686.00$ between "sometimes" and "almost always". Still in relation to the

Table 2. Relationship between education level and income with factors which affect the consumption of organic foods.

\begin{tabular}{|c|c|c|c|c|c|}
\hline DIMENSIONS & VARIABLES & PAGARM & FREQORG & CONFIAOR & OFINTER \\
\hline \multirow{5}{*}{ EDUCATION } & $<$ Elementary & $3.33 \mathrm{a}$ & $3.00 \mathrm{a}$ & $4.50 \mathrm{a}$ & $4.33 \mathrm{a}$ \\
\hline & Incomplete High School & $2.30 \mathrm{a}$ & $2.30 \mathrm{a}$ & $2.30 \mathrm{~b}$ & $3.30 \mathrm{a}$ \\
\hline & Incomp. Graduation & $2.41 \mathrm{a}$ & $2.54 \mathrm{a}$ & $3.16 \mathrm{ab}$ & $4.03 \mathrm{a}$ \\
\hline & Completed graduation & $2.58 \mathrm{a}$ & $2.87 \mathrm{a}$ & $3.21 \mathrm{ab}$ & $3.75 \mathrm{a}$ \\
\hline & Comp. Post-grad. & $2.67 \mathrm{a}$ & $3.01 \mathrm{a}$ & $3.17 \mathrm{ab}$ & $3.97 \mathrm{a}$ \\
\hline \multirow{5}{*}{$\begin{array}{l}\text { MONTHLY INCOME } \\
(\mathrm{R} \$)\end{array}$} & $<937.00$ & $2.35 \mathrm{c}$ & $2.66 \mathrm{~b}$ & $3.20 \mathrm{a}$ & $3.89 \mathrm{a}$ \\
\hline & $938.00-1,874.00$ & $2.42 \mathrm{bc}$ & $2.68 b$ & $3.28 \mathrm{a}$ & $4.00 \mathrm{a}$ \\
\hline & $1,875.00-2,811.00$ & $2.55 \mathrm{abc}$ & $2.83 \mathrm{ab}$ & $3.15 \mathrm{a}$ & $4.01 \mathrm{a}$ \\
\hline & $8,434.00-10,307.00$ & $2.70 \mathrm{abc}$ & $3.03 a$ & $3.16 \mathrm{a}$ & $3.76 \mathrm{a}$ \\
\hline & $>10,308.00$ & $2.80^{\mathrm{a}}$ & $3.09 \mathrm{a}$ & $3.20 \mathrm{a}$ & $3.77 \mathrm{a}$ \\
\hline
\end{tabular}

a,b,c: averages in the same column with different letters show statistically significant differences by the Tukey test $(\mathrm{p}<0.05)$. 
Table 3. Relationship between Brazilian regions and factors which affect the consumption of organic foods.

\begin{tabular}{lcccc}
\hline \multicolumn{1}{c}{ REGION OF BRAZIL } & PAGARM & FREQORG & CONFIAOR & OFINTER \\
\hline North & $2.49 \mathrm{a}$ & $2.73 \mathrm{bc}$ & $3.15 \mathrm{a}$ & $4.00 \mathrm{a}$ \\
Northeast & $2.50 \mathrm{a}$ & $2.68 \mathrm{c}$ & $3.14 \mathrm{a}$ & $3.88 \mathrm{a}$ \\
Central-west & $2.70 \mathrm{a}$ & $2.99 \mathrm{a}$ & $3.17 \mathrm{a}$ & $3.95 \mathrm{a}$ \\
Southeast & $2.56 \mathrm{a}$ & $2.86 \mathrm{abc}$ & $3.21 \mathrm{a}$ & $3.93 \mathrm{a}$ \\
South & $2.53 \mathrm{a}$ & $2.96 \mathrm{ab}$ & $3.40 \mathrm{a}$ & $4.02 \mathrm{a}$ \\
\hline
\end{tabular}

a,b,c: averages in the same column with different letters show statistically significant differences by the Tukey test $(\mathrm{p}<0.05)$.

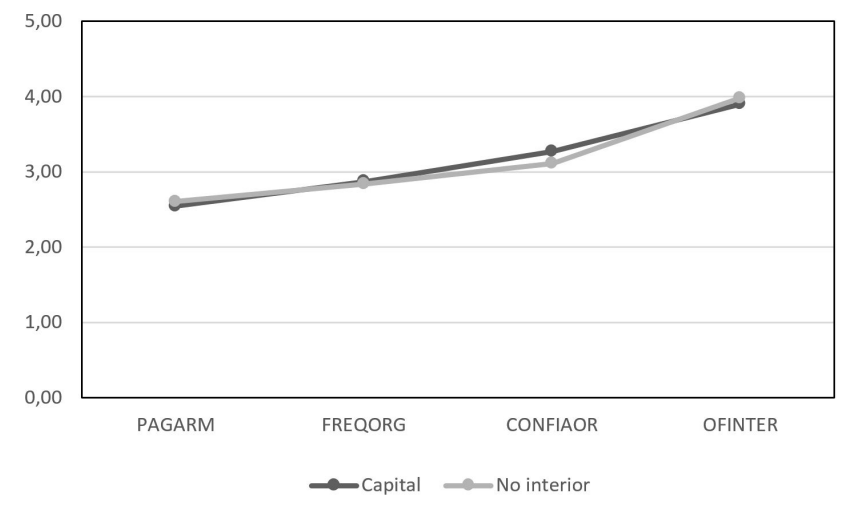

Figure 1. Relationship between place of residence and factors which affect the consumption of organic food.

consumption frequency, it is observed that people with monthly income below $\mathrm{R} \$ 1,874.00$ ( 2 minimum monthly salaries) reached statistically lower averages than those with income above $\mathrm{R} \$ 4,686.00$. Individuals with monthly income below $\mathrm{R} \$ 937.00$ and between $\mathrm{R} \$ 4,686.00$ and $\mathrm{R} \$ 6,559.00$ were shown to be "indifferent" to "interested" in consuming organic foods with functional potential, while the other groups presented themselves as "interested" to "very interested". The results observed herein are in agreement with the findings of Sinfh \& Verma (2017), who say that consumers with high income are more likely to buy organic food.

With regard to trust, all groups presented averages between "indifferent" to "trust". The homogeneous behavior of this study among the different groups with regard to the degree of confidence differs from the results obtained by Bryła (2016) in a study conducted in Poland. The obtained results show that individuals with lower monthly income did not show confidence in the certification and organic labeling system.

\subsection{Influence of the region and place of residence on the behavior of organic food consumers}

The different Brazilian regions showed similar behavior $(p>0.05)$ in relation to the PAGARM, CONFIAOR and OFINTER factors (Table 3). There was a statistical difference between the averages of the Northeast region in relation to the Midwest and South regions, and between North and Central West in the consumption frequency (FREQORG), but even so the values were between "almost never" and "sometimes" for all regions.

People who live in smaller cities and those who live in the state capitals have similar behavior in relation to the analyzed variables (Figure 1). Regardless of location, consumers are willing to pay 10 to $20 \%$ more for the purchase of organic cheese, consume organic food with a frequency between "almost never" and "sometimes", and show relative confidence ("indifferent" to "trust") that the food really is organic. This may be an indication that consumers, regardless of whether they live in the capital cities or in less urbanized locations, are concerned with assuming healthier eating habits, as highlighted by Bryła (2016). Therefore, the increased availability of these foods may attract a greater number of consumers (Massey et al., 2018).

It is also observed that the interviewees in relation to both the Brazilian regions (Table 3) and the place of residence (Figure 1) presented high averages in relation to the interest in consuming organic food with functional properties [variation between "indifferent" and "interested"]. Such behavior is possibly related to the high level of awareness of respondents about the benefits provided by these foods (Basha et al., 2015; Kapuge, 2016).

\section{Conclusion}

Young adults (31 to 40 years old), people over the age of 51 and widowers are willing to pay more and consume organic food more often, while young people under the age of 30 and people with low income tend to consume organic food less often. Regarding the interest in consuming organic foods with functional potential, all presented averages corresponding to values between "indifferent" to "interested", and people over the age of 60 had a slightly lower average. The highest consumption frequency among young people is related to the quality of these foods and the concern with personal appearance and family health. Residents of capital cities and smaller cities of the Brazilian states showed similar behavior for all analyzed variables. Widowers are willing to pay up to $30 \%$ more for the purchase of organic food $(p<0.05)$, while others would only pay between 10 and $20 \%$ more. The degree of confidence and interest in consuming organic foods with functional potential were practically not influenced by socio-demographic differences. 


\section{Acknowledgements}

We give thanks to the CAPES foundation for financial support.

\section{References}

Annunziata, A., \& Vecchio, R. (2016). Organic farming and sustainability in food choices: an analysis of consumer preference in Southern Italy. Agriculture and Agricultural Science Procedia, 8(1), 193-200. http://dx.doi.org/10.1016/j.aaspro.2016.02.093.

Assmann, G., Buono, P., Daniele, A., Della Valle, E., Farinaro, E., Ferns, G., Krogh, V., Kromhout, D., Masana, L., Merino, J., Misciagna, G., Panico, S., Riccardi, G., Rivellese, A., Rozza, F., Salvatore, F., Salvatore, V., Stranges, S., Trevisan, M., Trimarco, B., \& Vetrani, C. (2014). Functional foods and cardiometabolic diseases. Nutrition, Metabolism, and Cardiovascular Diseases, 24(12), 1272-1300. http:// dx.doi.org/10.1016/j.numecd.2014.10.010. PMid:25467217.

Apaolaza, V., Hartmann, P., D’souza, C., \& López, C. M. (2018). Eat organic-feel good? The relationship between organic food consumption, health concern and subjective wellbeig. Food Quality and Preference, 63(1), 51-628. http://dx.doi.org/10.1016/j.foodqual.2017.07.011.

Baldin, N., \& Munhoz, E. M. B. (2011, Novembro 7-10). Snowball (bola de neve): uma técnica metodológica para pesquisa em educação ambiental comunitária. In X Congresso Nacional de Educação EDUCERE. Curitiba, Brasil: PUCPR. Retrieved from https://educere. bruc.com.br/CD2011/pdf/4398_2342.pdf

Basha, M. B., Mason, C., Shamsudin, M. F., Hussain, H. I., \& Salem, M. A. (2015). Consumers atitude towards organic food. Procedia Economics and Finance, 31(1), 444-452. http://dx.doi.org/10.1016/ S2212-5671(15)01219-8.

Bezerra, M. F., Jamison, B. Y., Gomada, Y., Borges, K. C., Correia, R. T. P., \& Vattem, D. A. (2014). Antiaging and neuroprotective effects of Jambolan (Eugenia jambolana) L. via modulation of stress response signaling in C. elegans. The FASEB Journal, 28(S1)

Bozga, N.-A. (2015). The perception of Romanian consumer upon organic products' prices. Procedia Economics and Finance, 27(1), 190-198. http://dx.doi.org/10.1016/S2212-5671(15)01003-5.

Bryła, P. (2016). Organic food consumption in Poland: Motives and barriers. Appetite, 105(1), 737-746. http://dx.doi.org/10.1016/j. appet.2016.07.012. PMid:27417333.

Buder, F., Feldmann, C., \& Hamm, U. (2014). Why regular buyers of organic food still buy many conventional products: Product-specific purchase barriers for organic food consumers. British Food Journal, 116(3), 390-404. http://dx.doi.org/10.1108/BFJ-04-2012-0087.

Chekima, B., Oswald, A. I., Wafa, S. A. W. S. K., \& Chekima, K. (2017). Narrowing the gap: factores driving organic food consumption. Journal of Cleaner Production, 166(1), 1438-1447. http://dx.doi. org/10.1016/j.jclepro.2017.08.086.

Denver, S., \& Christensen, T. (2015). Organic food and health concerns: A dietary approach using observed data. NJAS Wageningen Journal of Life Sciences, 74-75(1), 9-15. http://dx.doi.org/10.1016/j.njas.2015.05.001.

Food and agriculture Organization of the Unites Nation - FAO. (2016). What is organic agriculture? Retrieved from http://www.fao.org/ organicag/oa-faq/oa-faq1/en.

Gottschalk, I. R., \& Leistner, T. (2013). Consumer reactions to the availability of organic food in discount supermarkets. International
Journal of Consumer Studies, 37(2), 136-142. http://dx.doi. org/10.1111/j.1470-6431.2012.01101.x.

Hwang, J. (2016). Organic food as self-presentation: the role of psychological motivation in older consumers' purchase intention of organic food. Journal of Retailing and Consumer Services, 28(1), 281-287. http://dx.doi.org/10.1016/j.jretconser.2015.01.007.

Instituto Brasileiro de Geografia e Estatística - IBGE. (2016). Pesquisa nacional por amostra de domicílios: síntese de indicadores 2015. Coordenação de Trabalho e Rendimento. Rio de Janeiro: IBGE, 2016.

IFOAM Organic International. (2016). Organic Basic. Retrieved from https://www.ifoam.bio/en/our-library/organic-basics.

Janssen, M. (2018). Determinants of organic food purchases: evidence from household painel data. Food Quality and Preference, 68(1), 19-28. http://dx.doi.org/10.1016/j.foodqual.2018.02.002.

Kapuge, K. D. L. R. (2016). Determinants of organic food buying behavior: special reference to organic food purchase intention of Sri Lankan customers. Procedia Food Science, 6(1), 303-308. http:// dx.doi.org/10.1016/j.profoo.2016.02.060.

Krauss, A., Annunziata, A., \& Vecchio, R. (2017). Sociodemografic factors differentiating the consumer and motivations for functional food consumption. Journal of the American College of Nutrition, 36(2), 1-11. http://dx.doi.org/10.1080/07315724.2016.1228489.

Lee, H., \& Yun, Z. (2015). Consumers' perceptions of organic food attributes and cognitive and affective attitudes as determinants of their purchase intentions toward organic food. Food Quality and Preference, 39(1), 259-267. http://dx.doi.org/10.1016/j.foodqual.2014.06.002.

Marian, L., Chrysochou, P., Krystallis, A., \& Thøgersen, J. (2014). The role of price as a product attribute in the organic food context: An exploratiom based on actual purchase data. Food Quality and Preference, 37(1), 52-60. http://dx.doi.org/10.1016/j.foodqual.2014.05.001.

Massey, M., O'cass, A., \& Otahal, P. (2018). A meta-analitic study of the factors driving the purchase of organic food. Appetite, 125(1), 418427. http://dx.doi.org/10.1016/j.appet.2018.02.029. PMid:29501680.

Mitsuoka, T. (2014). Development of funcional foods. Bioscience of Microbiota, Food and Health, 33(3), 117-128. http://dx.doi. org/10.12938/bmfh.33.117. PMid:25032085.

Prakash, G., Singh, P. K., \& Yadav, R. (2018). Application of Consumer Style Inventory (CSI) to predict young Indian consumer's intention to purchase organic food products. Food Quality and Preference, 68(1), 90-97. http://dx.doi.org/10.1016/j.foodqual.2018.01.015.

Seconda, L., Péneau, S., Bénard, M., Alles, B., Hercberg, S., Galan, P., Lairon, D., Baudry, J., \& Kesse-Guyot, E. (2017). Is organic food consumption associated with life satisfaction? A cross-sectional analysis from the NutriNet-Santé study. Preventive Medicine Reports, 8(C), 190-196. http://dx.doi.org/10.1016/j.pmedr.2017.10.014. PMid:29881668.

Sinfh, A., \& Verma, P. (2017). Factors influencing indian consumer's actual buying behavior towards organic food products. Journal of Cleaner Production, 167(1), 473-483. http://dx.doi.org/10.1016/j. jclepro.2017.08.106.

Yadav, R., \& Pathak, G. S. (2016). Intention to purchase organic food among young consumers: Evidences from a developing nation. Appetite, 96(1), 122-128. http://dx.doi.org/10.1016/j.appet.2015.09.017. PMid:26386300. 